Japanese Journal of Herpetology 11(3) : 145-151. 1986.

\title{
The Alteration Pattern of Dorsal Scale Rows in the Yellow-Lipped Sea Snake Laticauda colubrina, with special Reference to Sexual Dimorphism
}

\author{
Hidetoshi Ota*, Michihisa Toriba** and Hiroshi TAKAHAShi***
}

\begin{abstract}
The alteration pattern of dorsal scale rows in the yellow-lipped sea snake $L a$ ticauda colubrina was investigated and compared between the sexes. In the female, the number of scale rows once increased in the anterior part of the body and was subsequertly reduced three times posteriorly, whereas that in the male showed only two reductions. The addition and one reduction in the female were unique to that sex. The last two reductions were common to both sexes, but appeared more posteriad in the female than in the male.
\end{abstract}

\section{INTRODUCTION}

Detailed investigations on the addition-reduction pattern of scale rows have been made chiefly for terrestrial snakes (e.g. Clark and Inger, 1942; Gans, 1964; Thomas and Dixon, 1976). For sea snakes, however, there is no report on this alteration pattern except for brief data on scale rows in the neck, midbody, the thickest part of the body, and in front of the cloaca (e.g., Smith, 1926; McDowell, 1972; Burger and Natsuno, 1974; Cogger, 1975; Mao and Chen, 1980), but some authors demonstrated that scutellations of several sea snake species are numerically remarkably variable in comparison with the terrestrial forms (Marx and Rabb, 1972; Voris, 1975).

The yellow-lipped sea snake Laticauda colubrina is widely distributed in the tropical and subtropical regions of the Pacific and Indian Oceans north to the waters adjacent to Japan (Smith, 1926). Pernetta (1977) stated that the number of midbody scale rows of this sea snake is significantly larger in the female than in the male

* Department of Zoology, Faculty of Science, Kyoto University, Kitashirakawa-oiwakecho, Sakyo-ku, Kyoto, 606 Japan 606 京都市左京区北白川追分町 宗都大学理学部動物学教室

** Japan Snake Institute, Yabuzuka-honmachi, Nitta-gun, Gunma, 379-23 Japan 379-23 群馬県新田郡藪塚本町湯の入 日本蛇族学術研究所

*** Japan Snake Institute Okinawa Branch, Maekawa, Tamagusuku-son, Okinawa, 901-06 Japan Present address : Taishibashi-3, 2-6-1003, Asahi-ku, Osaka, 535 Japan 901-06 沖縄県島尻郡玉城村字前川1336 日本蛇族学術研究所沖縄支所 現住所：干535 大阪市旭区太子橋 3 丁目2-6-1003 
based on specimens collected from around Fiji Island. From Japan, only a few specimens had long been known for this species (Nakamura and Uéno, 1963). Recently, however, Ota et al. (1985) reported on several specimens collected from around the Ryukyu Archipelago, which also showed sexual dimorphism in the midbody scale rows. Additional specimens obtained thereafter enabled us to investigate the alteration pattern of scale rows of this species in detail. Thus, here we describe the locations where additions and reductions occur and the scale rows involved in these alterations, and elucidate the sexual dimorphism, as well as the characteristics of the pattern by comparing it with alteration patterns of terrestrial snakes mentioned in the literature.

\section{MATERIALS AND METHODS}

Six males and 13 females collected from the water around the Ryukyu Archipelago and deposited in the Japan Snake Institute (JFS), Japan Snake Institute Okinawa Branch (OJFS), Osaka Museum of Natural History (OMNH) or National Science Museum, Tokyo (NSM), were examined. One male, recently captured at Ishigakijima of the Ryukyu Archipelago, was also measured. The number of ventrals (VT) was counted using Dowling's (1951a) system, and subcaudal (SC) and scale counts were also taken.

The number of scale rows was investigated beginning just above the first ventral sensu Dowling (1951a) backward to the vicinity of the cloaca, and locations of additions and reductions were noted for each specimen. Each alteration site was referred to the number of ventrals anterior to the one entering the imaginary vertical line from the altering scale, following the format of Dowling (1951b). The distance of each alteration site from the cloaca was indicated with the number of intervening ventrals.

Clark and Inger (1942) used the word bilateral for alterations occurring on opposite sides of the body over closely approximated, although not always just the same, ventrals. Later, Thomas and Dixon (1976) used the word unilateral for alterations observed to occur randomly, irrespective of locations, in a few scales' length on only one side of the body. They regarded the bilateral alteration as most meaningful, and noted that unilateral alterations may be disregarded. Accordingly, here we described the increase and reduction of body scale rows based on the bilateral alterations, though there were also several unilateral alterations.

Statistical significances of the correlations, and the sexual differences in VT and $\mathrm{SC}$ were examined by t-test and Kruskal-Wallis test, respectively. 


\section{RESULTS}

The results of the ventral and the subcaudal counts of the present specimens are given in Table 1. The ventral count of the females was significantly larger than that of the males $(\mathrm{P}<0.001)$. On the contrary, the subcaudal count was larger in the males than in the females $(\mathrm{P}<0.001)$, resulting in a similar total count for both sexes.

Table 1. The numbers of ventrals, subcaudals, and their total $\left(\overline{\mathrm{X}}_{ \pm} \mathrm{SD}\right.$, followed by ranges in parenthesis) of Laticauda colubrina.

\begin{tabular}{lcccc}
\hline Sex & N & Ventrals & Subcaudals & Total \\
\hline Female & 13 & $236.85 \pm 1.77$ & $35.38 \pm 1.56$ & $272.23 \pm 2.77$ \\
& & $(233-239)$ & $(33-38)$ & $(268-276)$ \\
Male & 7 & $229.00 \pm 4.32$ & $43.43 \pm 1.81$ & $272.43 \pm 5.50$ \\
& & $(222-235)$ & $(40-45)$ & $(262-279)$ \\
\hline
\end{tabular}

Alteration patterns. Six male specimens had 23 scale rows on the neck, whereas the other (OJFS 0027) possessed 21 rows. In all males, the number of scale rows was 19 in the vicinity of the cloaca. In the females, the number of neck scale rows was 23 in 11 and 25 in two specimens, and subsequently reduced to 19 and 21 , respectively.

The modal pattern of the males comprised two reductions in the posterior part of the body. Here we call these reductions the first (FPR) and the second primary reductions (SPR). On the other hand, the females showed a pair of alterations, addition $(A D)$ and reduction (secondary reduction $=S R$ ), besides two reductions equivalent to the primary reductions in the male (Fig. 1). Two males showed variation in the alteration pattern: scale row alteration in one (OJFS 0027) differed from the modal pattern in having one addition on the neck, and that in the other (OJFS 0026) showed a reduction and a subsequent addition in the anterior part of the body.

Scale rows involved in the alterations. The first primary reduction occurred by the fusion of the fifth and the sixth or the sixth and the seventh scale rows, or the dropping out of the sixth row. The second primary reduction took place by either fusion of the fourth and the fifth, the fifth and the sixth, the sixth and the seventh or the ninth and the tenth rows, or the loss of the fifth or the sixth row. The secondary reduction occurred by the fusion of either the fifth and the sixth, the sixth and the seventh or the seventh and the eighth rows, or the dropping out of the sixth or the seventh row. The addition in the females resulted from the division of the 


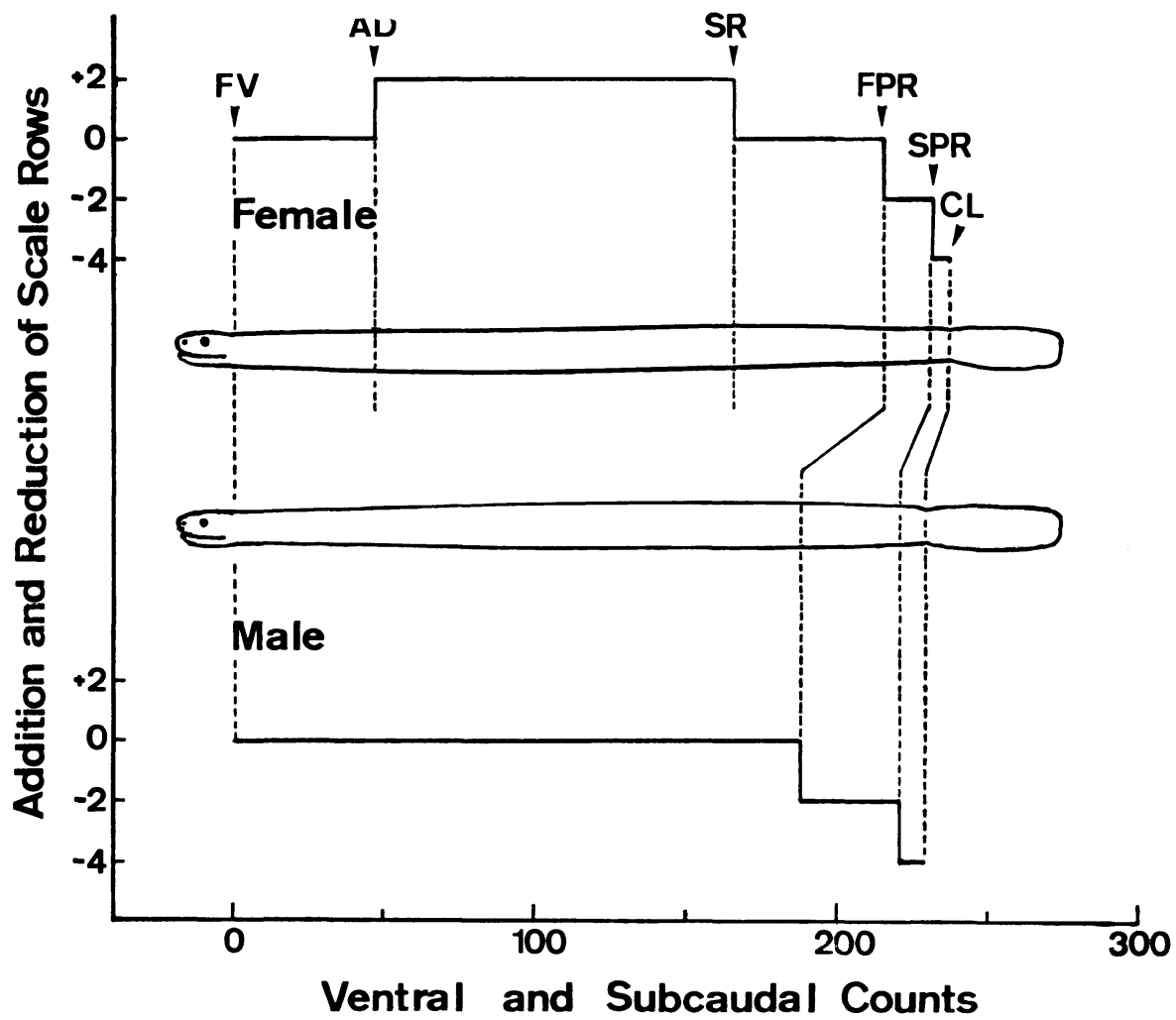

Fig. 1. Alteration of scale rows, and means of sites of first ventral (FV), addition (AD), first primary reduction (FPR), second primary reduction (SPR), secondary reduction (SR), and cloaca (CL) in the left side body of male and female Laticauda colubrina.

sixth or the seventh row. The addition in OJFS 0027 and OJFS 0026 occurred by the division of the sixth and the first rows, respectively. The extra reduction of OJFS 0026 resulted from the fusion of the second and the third rows.

Alteration sites. The mean site of each alteration in the left side of the body is shown in Fig. 1 and Table 2 along with the location of the cloaca. The sites of both FPR and SPR were significantly more posteriar in the female than in the male $(\mathrm{P}<0.001)$. The distance of FPR from the cloaca was larger in the males $(\overline{\mathrm{X}}=40.71, \mathrm{SD}=15.43)$ than in the females $(\overline{\mathrm{X}}=24.31, \mathrm{SD}=10.58 ; \mathrm{P}<0.001)$, whereas that of SPR showed no sexual difference (males: $\bar{X}=7.85, S D=3.44$; femalse: $\bar{X}=5.46$, $\mathrm{SD}=4.43)$.

In the females, each correlation of sites of AD, FPR, or SR to VT was not significant $(\mathrm{P}>0.05)$, and only the site of SPR showed significant positive correlation with VT $(r=0.588, d F=11, P<0.05)$. In the males, on the other hand, both FPR and SR 
Table 2. Sites of addition (AD), secondary reduction (SR), and first (FPR) and second primary reductions (SPR) in the left side of body $(\overline{\mathrm{X}} \pm \mathrm{SD}$, followed by ranges in parenthesis) of male and female Laticauda colubrina.

\begin{tabular}{lccccc}
\hline Sex & N & AD & SR & FPR & SPR \\
\hline Female & 13 & $46.85 \pm 21.17$ & $165.31 \pm 10.21$ & $214.67 \pm 8.04$ & $231.00 \pm 5.12$ \\
& & $(23-92)$ & $(147-178)$ & $(204-229)$ & $(221-239)$ \\
Male & 7 & - & - & $188.29 \pm 18.01$ & $221.14 \pm 7.06$ \\
& & & & $(161-214)$ & $(213-233)$ \\
\hline
\end{tabular}

showed significant correlation with VT $(r=0.673, d F=5, P<0.05 ; r=0.929, d F=5$, $\mathrm{P}<0.01)$.

\section{DISCUSSION}

Besides Laticauda colubrina, several species of terrestrial snakes such as Bothrolycus ater, Chironius scurrulus, C. fuscus, Lampropeltis trianguium (Boulenger, 1919; Thomas and Dixon 1976; Williams, 1978) were reported to differ sexually in dorsal scale row counts. At least, one sea snake species, Hydrophis ornatus, also seems to have sexual dimorphism (from the data in Mittleman, 1947). In these species, female has, at least in a part of the body, the larger number of transverse scales than males.

Procter (1919) postulated that the female snakes have greater stress in the posterior quarter of the body with the development of the young, and that subsequent growth of girth involved the increase of scale rows. In Laticauda colubrcna, however, the addition occurs in the anterior part of the body of the female as in Bothrolycus ater (Boulenger, 1919). This fact suggests that the sexual dimorphism in the alteration pattern of scale rows in this species is due also to other factors such as accumulation of fat and exploitaton of large prey, which make the relative body diameter of the female larger.

Thomas and Dixon(1975), based on the data from geographic variation of Elaphe quadrivittata, stated that additions-reductions of scale rows tend to occur more posteriad with the increment of VT. Thomas (1976) also demonstrated the correlation between the reduction sites and VT in Philodryas olfersi, and postulated that the point of reduction shifts backward as VT increases. In Laticauda colubrina, sites of FPR and SPR of the male and SPR of the female were clearly correlated with ventral counts, whereas those of $A D, F P R$ and $S R$ in the female did not show such correlation, probably due to the small range of variation in VT. The location of 
FPR differs from that of SPR in relation to the position of the cloaca. Distance of SPR from the cloaca was almost constant irrespective of the sex, and its location seemed to vary according to the position of the cloaca. On the other hand, FPR in the male occurred anterior to that in the female when measured from the cloaca.

Two types of alterations involving the sexual dimorphism are recognizable in this sea snake:

1) reductions common to both sexes-FPR and SPR, and

2) addition and reduction unique to the female-AD and SR.

Studies on the relationships between the geographic variation of VT and of the alteration sites may reveal whether or not the sites of $A D, S R$ and FPR in the female are correlated to VT.

\section{Specimens examined}

JFS 1479, 1480, 2441, 2462, 2715, 2716 ; OJFS 0024, 0025, 0026, 0027, 0028, 0029, 0030, 0031, 0032, 0033 ; OMNH R 888, 2322 ; NSM H 03496 ; Ota's Private Number (OPN) 4682.

\section{ACKNOWLEDGMENTS}

We wish to thank Yasuhiko Shibata (Osaka Museum of Natural History) and Shun-Ichi Uéno (National Science Museum, Tokyo) for the loan of specimens. We are also indebted to Naoki Kamezaki and Kazuo Itoman for the supply of specimens they captured. Special thanks are due Tsutomu Hikida and Masafumi Matsui for critically reviewing the manuscript.

This work was supported in part by a Grant-in Aid for Special Project Research on Biological Aspects of Optimal Strategy and Social Structure from the Japan Ministry of Education, Science and Culture.

\section{LITERATURE CITED}

Boulenger, G. A. 1919. Un cas de dimorphism sexuel chez un serpent Africain (Bothrolycus ater Gunth.). Inst. France C. R. Acad. Sci. $169: 606-607$.

Burger, W. L. and T. Natsuno. 1974. A new genus for the Arafura smooth seasnake and redefinitions of other seasnake genera. Snake $6: 61-75$.

Clark, P. J. and R. F. Inger. 1942. Scale reductions in snakes. Copeia $1942: 163-170$.

Cogger, H. G. 1975. Sea snakes of Australia and New Guinea. In: W. A. Dunson ed. The biology of sea snakes. University Park Press, Baltimore, London, Tokyo. pp. 59-139.

Dowling, H. G. 1951a. A proposed standard system of counting ventrals in snakes. Brit. Jour. Herpetol. $1: 97-99$. 
Dowling, H. G. 1951b. A proposed method of expressing scale reductions in snakes. Copeia 1951: 131 -134 .

Gans, C. 1964. A redescription of, and geographic variation in, Liophis miliaris Linné, the common water snake of southeastern South America. Amer. Mus. Novitates 2178 : 1-58.

Mao, S.-H. and B.-Y. Chen. 1980. Sea snakes of Taiwan-a natural history of sea snakes. NSC Special Publication No. 4, The National Science Council, Taipei. 64p.

Marx, H. and G. B. Rabb. 1972. Phyletic analysis of fifty characters of advanced snakes. Fieldiana : Zool. $63: 1-321$.

McDowell, S. B. 1972. The genera of sea-snakes of the Hydrophis group. Transact. Zool. Soc. London $32(3): 189-247$.

Mittleman, M. B. 1947. Geographic variation in the sea snake, Hydrophis ornatus (Gray). Proc. Biol. Soc. Washington $60: 1-8$.

Nakamura, K. and S.-I. Uéno. 1963. Japanese reptiles and amphibians in colour. Hoikusha, Osaka. 214p. (in Japanese)

Ota, H., H. Takahashi and N. Kamezaki. 1985. On the specimens of yellow lipped sea krait Laticauda colubrina from the Yaeyama Group, Ryukyu Archipelago. Snake 17 : 156-159.

Pernetta, J. C. 1977. Observations on the habits and morphology of the sea snake, Laticauda colubrina (Schneider) in Fiji. Can. Jour. Zool. $55: 1612-1619$.

Procter, J. B. 1919. On the variation in the number of dorsal scale-rows in our British snakes. Proc. Zool. Soc. London, 1919 : 357-364.

Smith, M. A. 1926. Monograph of the sea snakes. Oxford Univ. Press, London. 130p.+2pls.

Thomas, R. A. 1976. Dorsal scale row formulae in snakes. Copeia $1976: 839-841$.

Thomas, R. A. and J. R. Dixon. 1976. Scale row formulae in Elaphe guttata (Linnaeus) and notes on their interpretation. Nat. Hist. Miscellanea $195: 1-5$.

Voris, H. K. 1975. Dermal scale-vertebra relationships in sea snakes (Hydrophiidae). Copeia $1975: 746$ -755 .

Williams, K. L. 1978. Systematics and natural history of the American milk snake, Lampropeltis triangulum. Publications Biol. Geol. Milwaukee Publ. Mus. 2: 1-258.

$$
\begin{array}{ccc}
\text { 要 } & \text { 旨 } \\
\text { アオマダラウミヘビ Laticauda } & \text { colubrina } & \text { に打ける体鱗列の変動パタンと性的二型 }
\end{array}
$$

太田 英利・烏羽 通久・高橋＼cjkstart寛

日本近海で採集されたアオマダラウミへビに拈ける体鱗列数の変動を調べ，そのパタンにつ いて検討した。雌では鱗列数は体の前部で 1 回增加し, 後部で 3 回にわたり減少した。これに 対し雄では, 体の後部で雌と共通の 2 回の減少のみが見られた。これらの減少は雌では雄に比 ベて, より後方で認められた。 